\title{
ANALISIS KESALAHAN SISWA DALAM MENYELESAIKAN SOAL MATRIKS DAN KAITANNYA DENGAN MOTIVASI BELAJAR MATEMATIKA PADA KELAS XI
}

\author{
Nurul Ainin'), Wahyu Hartono ${ }^{2)}$, Jaenal Aripin ${ }^{3)}$ \\ 1,2 Universitas Swadaya Gunung Jati, Cirebon,Indonesia \\ 1nurulainin1323@gmail.com; 2wahyuhartono.id@gmail.com; \\ ${ }_{3}^{3}$ SMA Negeri 1 Babakan, Cirebon, Indonesia; jaenalaripin259@gmail.com
}

\begin{abstract}
Abstrak
Matematika merupakan pelajaran yang cukup sulit dibandingkan dengan mata pelajaran lainnya. Materi matematika di SMA terdiri dari banyak sub materi, diantaranya materi matriks. Berdasarkan data dari hasil ulangan harian pada tahun sebelumnya, didapatkan hasil bahwa nilai dari beberapa siswa pada materi matriks kurang memuaskan. Hal tersebut dikarenakan beberapa siswa melakukan kesalahan dalam mengerjakan soal terkait materi matriks. Oleh karena itu, Penelitian ini mempunyai tujuan untuk mendeskripsikan kesalahan siswa dalam menyelesaikan soal matriks. Penelitian ini penelitian deskriptif kualitatif. Adapun subjek dalam penelitian ini diambil dari siswa kelas XI SMA Negeri 1 Babakan tahun akademik 2019/2020. Metode pengumpulan data yang digunakan pada penelitian ini adalah menggunakan metode tes dan angket yang berisi penyataan yang memuat motivasi siswa dalam pembelajaran matematika. Data dianalisis kemudian ditarik suatu kesimpulan. Dari hasil penelitian didapat hasil bahwa siswa melakukan 9 jenis kesalahan, yaitu Kesalahan dalam pengoperasian bilangan, kesalahan memahami konsep persamaan matriks, kesalahan dalam menentukan rumus invers matriks, kesalahan dalam menentukan determinan pada matriks, kesalahan dalam menentukan adjoin matriks, kesalahan dalam mengubah soal cerita kedalam kalimat matematika, kesalahan dalam hasil perhitungan, kesalahan dalam melanjutkan proses penyelesaian, kesalahan dalam menentukan hasil akhir.
\end{abstract}

Kata Kunci : Analisis; Kesalahan; Motivasi; Matriks.

Mathematics is a fairly difficult subject compared to others. Mathematical material in high school consists of many sub-materials, including matrix. Based on data from the results of daily tests in the previous year, it was found that the scores of some students on the matrix material were unsatisfactory. This is because some students made mistakes in working on questions related to the matrix. Therefore, this study aims to describe students' errors in solving matrix problems. This research is a qualitative descriptive study. The subjects in this study were taken from class XI students of SMA Negeri 1 Babakan in the 2019/2020 academic year. The data collection method used in this study was to use a test method and a questionnaire containing statements that contained student motivation in learning mathematics. The data were analyzed then a conclusion was drawn. The results showed that the students made 9 types of errors, namely errors in number operations, errors in

Euclid, p-ISSN 2355-1712, e-ISSN 2541-4453, Vol. 7, No. 2, pp. 77- 147

CLembaga Penelitian Universitas Swadaya Gunung Jati (UGJ), Cirebon. 
understanding the concept of matrix equations, errors in determining the inverse matrix formula, errors in determining the determinants of the matrix, errors in determining matrix adjoin, errors in changing the story problem into Mathematical sentences, errors in calculation results, errors in continuing the solving process, errors in determining the final result.

\section{PENDAHULUAN}

Matematika merupakan sebuah ilmu dasar untuk membantu memahami ilmu pengetahuan yang lain. (Rahmat, 2013). Matematika merupakan ilmu yang penting untuk ilmu lainnya seperti yang diungkapkan oleh wahyudin (2002) yang menyatakan bahwa matematika merupakan cabang utama ilmu dari ilmu filsafat yang menjadi ibu dari segala ilmu, oleh karena itu matematika merupakan ilmu pokok yang diajarkan kepada seluruh siswa disetiap jenjang pendidikan.tetapi disisi lain matematika juga dianggap sebagai mata pelajaran yang cukup sulit dibandingkan dengan mata peljaran lainnya, bahkan cukup menakutkan bagi siswa. Pernyataan tersebut diungkapkan oleh Nawangsari (2007) bahwa matematika sejak dulu memang dianggap oleh siswa sebagai pelajaran yang sulit dan menakutkan. Menurut Cooney (Yusmin,1996), kesulitan siswa dalam mempelajari matematika diklasifikasikan kedalam tiga jenis kesulitan yaitu 1) kesulitan siswa dalam menggunakan konsep, 2) kesulitan siswa dalam menggunakan prinsip, 3) kesulitan siswa dalam menyelesaikan masalah-masalah verbal. kesulitan siswa dalam mempelajari matematika juga bisa dikarenakan kurangnya motivasi belajar pada diri siswa sendiri seperti pada hasil penelitian Fitriati T.K (2017) yang mengungkapkan bahwa siswa yang memperoleh nilai matematika yang masih dibawah nilai ketuntasan sebesar $48 \%$ dan berdasarkan hasil nilai assessment motivasi terdapat $28 \%$ siswa yang masih memiliki motivasi rendah pada mata pelajaran matematika. oleh karena itu motivasi belajar siswa bisa mempengaruhi kesulitan siswa dalam mempelajari matematika yang menyebabkan kesalahan siswa dalam menjawab soal -soal matematiaka. Kesalahan adalah suatu bentuk penyimpangan terhadap jawaban yang sebenarnya yang bersifat sistematis (Ardiawan, 2015). Analisis kesalahan adalah suatu upaya untuk mengamati, menemukan, dan mengklasifikasi kesalahan dengan aturan tertentu (Astuty \& Wijayanti, 2013). Sebagaimana menurut (Astuty \& Wijayanti, 2013; Siswandi \& Sujadi, 2016; Umam, 2014) Kesalahan-kesalahan peserta didik perlu dianalisis untuk mengetahui beragam kesalahan yang dilakukan oleh peserta didik. Melalui analisis tersebut akan diperoleh jenis dan letak kesalahan, sehingga pendidik dapat memberikan solusi yang tepat agar dapat diperbaki dan tidak terulang lagi dan informasi kesalahan dalam 
menyelesaikan soal-soal matematika dapat digunakan untuk meningkatkan efektivitas pembelajaran matematika.

Materi matematika di SMA terdiri dari banyak sub materi, diantaranya materi matriks. Kajian mengenai matriks sangat luas, adapun materi yang dikaji pada matriks yaitu kita mempelajari istilah-istilah dalam matriks, jenis-jenis matriks, transpose matriks, kesamaan matriks dan operasai pada matriks yaitu diantaranya adalah penjumlahan matriks, pengurangan matriks, perkalian matriks, determinan, invers, persamaan matriks dan penyelesaikan sistem persamaan linear baik menggunakan matriks maupun determinan. Berdasarkan data dari hasil ulangan harian pada tahun sebelumnya, didapatkan hasil bahwa nilai dari beberapa siswa pada materi matriks kurang memuaskan. Hal tersebut dkarenakan beberapa siswa melakukan kesalahan dalam mengerjakan soal terkait materi matriks yaitu pada pengoprasian matriks, determinan matrik, persamaan matriks dan penyelesaian sistem persamaan linear baik menggunakan metode matriks maupun determinan.

Berdasarkan uraian penjelasan dan penelitian terdahulu, perlu adanya analisis tentang kesalahan siswa dalam menyelesaikan soal pada mata pelajaran matematika yaitu materi matriks agar dapat mengetahui dan mengidentifikasi yang selanjutnya mendeskripsikan secara lebih jelas kesalahan apa saja yang dilakukan oleh siswa. Disamping itu pada penelitian ini juga akan digali mengapa siswa melakukan kesalahan tersebut, agar para pengajar mengetahui penyebab siswa melakukan kesalahan dan dapat memperbaiki melalui pembelajaran.

\section{METODE}

Penelitian ini merupakan penelitian deskriptif kualitatif. penelitian ini mempunyai tujuan untuk mendeskripsikan kesalahan siswa dalam menyelesaikan soal matriks dan kaitannya dengan motivasi belajar matematika pada kelas XI. Adapun subjek dalam penelitian ini diambil dari siswa kelas XI SMA Negeri 1 Babakan tahun akademik 2019/2020 dengan kriteria:1) jawaban siswa mewakili kesalahan yang banyak dilakukan oleh siswa, 2) jawabannya relatif relevan dengan soal tes, 3) mempunyai komunikasi yang baik. Instrumen utama dalam penelitian ini adalah peneliti sendiri, karena dalam penelitian ini peneliti sebagai penentu dalam mengumpulkan, menganalisis dan menyajikan data. Sedangkan instrumen bantu dalam penelitian ini adalah soal tes matriks dan angket motivasi belajar siswa sebagai pendukung penelitian. Teknik pengumpulan data yang digunakan pada penelitian ini adalah teknik analisa pada setiap butir soal uraian dan teknik komunikasi tidak langsung berupa angket. Adapun tes

Euclid, p-ISSN 2355-1712, e-ISSN 2541-4453, Vol. 7, No. 2, pp. 77- 147

(CLembaga Penelitian Universitas Swadaya Gunung Jati (UGJ), Cirebon. 
yang digunakan berupa pemberian soal bentuk uraian terkait materi matriks, diberikan kepada siswa kelas XI yang mempelajari materi matriks. Tes tersebut diberikan setelah memperoleh materi matriks. Angket pada penelitian ini berupa pertanyaan-pertanyaan motivasi siswa dalam pembelajaran matematika. Angket tersebut sebagai pendukung penelitian apakah ada kaitannya antara motivasi siwa dengan kesalahan siwa dalam menjawab soal matematika. Sebelum peneliti melakukan analisis peneliti melalui langkah-langkah 1. menentukan waktu penelitian, 2. memberikan tes berupa soal uraian yang akan di analisa, 3. mengambil subjek yang jawabannya mewakili kesalahan yang banyak dilakukan siswa, 4 . menganalisa jawaban siswa, 5. menyebar angket kepada siwa yang telah ditentukan. Kemudian pada tahap akhir peneliti menganalisa data yang telah diperoleh yang selanjutnya ditarik suatu kesimpulan.

\section{HASIL DAN PEMBAHASAN}

Penelitian yang dilakukan bertujuan untuk mengetahui apa saja kesalahankesalahan siswa dalam menjawab soal materi matriks dan kaitannya dengan motivasi belajar matematika pada siswa kelas XI, sekaligus untuk menjadi acuan agar pada pembelajaran selanjutnya bisa dilakukan dengan lebih baik lagi. Pada penelitian ini siswa diberikan soal uraian terkait materi matriks, setelah siswa memperoleh materi tersebut. siswa tidak diperbolehkan membuka buku catatan selama mengerjakan soal tersebut. Berikut ini adalah soal yang diberikan kepada siswa, yaitu:

1. Tentukan determinan dari matriks berikut!

$$
A=\left(\begin{array}{ccc}
2 & 1 & 6 \\
3 & -1 & -3 \\
0 & 1 & 4
\end{array}\right)
$$

2. Tentukan Matriks $X$ dari persamaan berikut !

$$
\left(\begin{array}{ll}
2 & 1 \\
3 & 4
\end{array}\right) X=\left(\begin{array}{ll}
5 & 2 \\
2 & 4
\end{array}\right)
$$

3. Umur Anin 6 tahun lebih tua dari umur Dzul, sedangkan jumlah umur mereka adalah 36 tahun. berapakah umur mereka masing-masing? Petunjuk : gunakan matriks atau metode determinan

Setelah semua siswa mengerjakan soal tersebut, selanjutnya peneliti menelaah jawaban siswa untuk mendapatkan subjek penelitian. Berdasarkan kriteria yang sudah ditetapkan oleh peneliti, terdapat siswa yang memenuhi kriteria yang telah ditetapkan. kemudian peneliti menganalisis hasil tes yang diperoleh siswa dengan memperhatikan apa saja kesalahan siswa dalam menyelesaikan soal tes tersebut. Setelah dianalisis pada lembar jawaban siswa tersebut diperoleh: 
Berikut ini adalah jawaban tertulis siswa berdasarkan soal nomor 1:

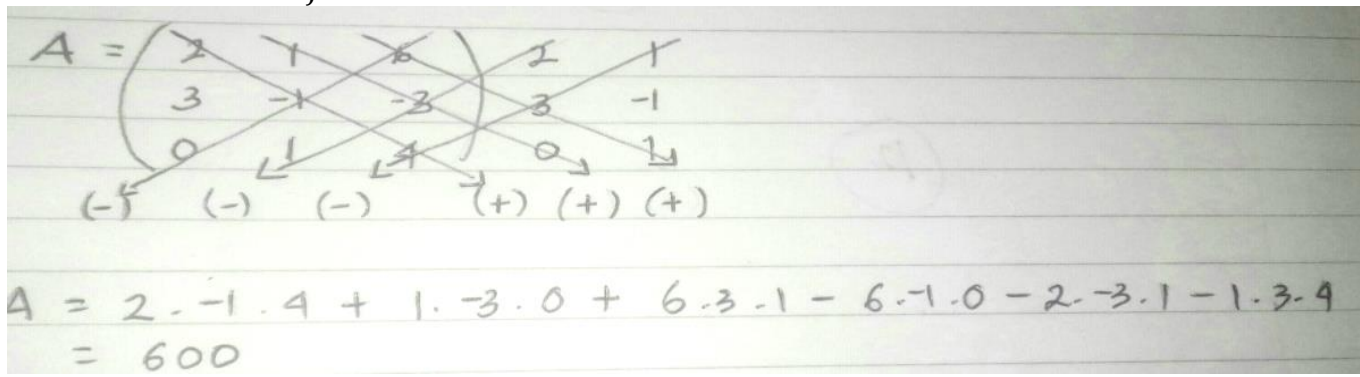

\section{Gambar 1. Jawaban Soal Nomor 1}

Berdasarkan hasil dari jawaban tertulis pada soal nomor 1, didapatkan beberapa kesalahan yang dilakukan oleh siswa, yaitu: siswa sudah tepat dalam menggunkan konsep metode sarrus untuk mengetahui determinan A seperti yang terlihat pada gambar 1. Namun siswa masih mengalami kesulitan dalam melakukan kegiatan perhitungan hal ini sejalan dengan pendapat Wiyartimi dkk (2010:91) yang mengatakan bahwa ada beberapa jenis kesalahan yang dilakukan siswa salah satunya ialah kesalahan operasi, yaitu kesalahan siswa dalam menggunakan operasi matematika. Oleh karena itu, siswa salah dalam menentukan hasil selanjutnya.

Berikut ini adalah jawaban tertulis siswa berdasarkan soal nomor 2:

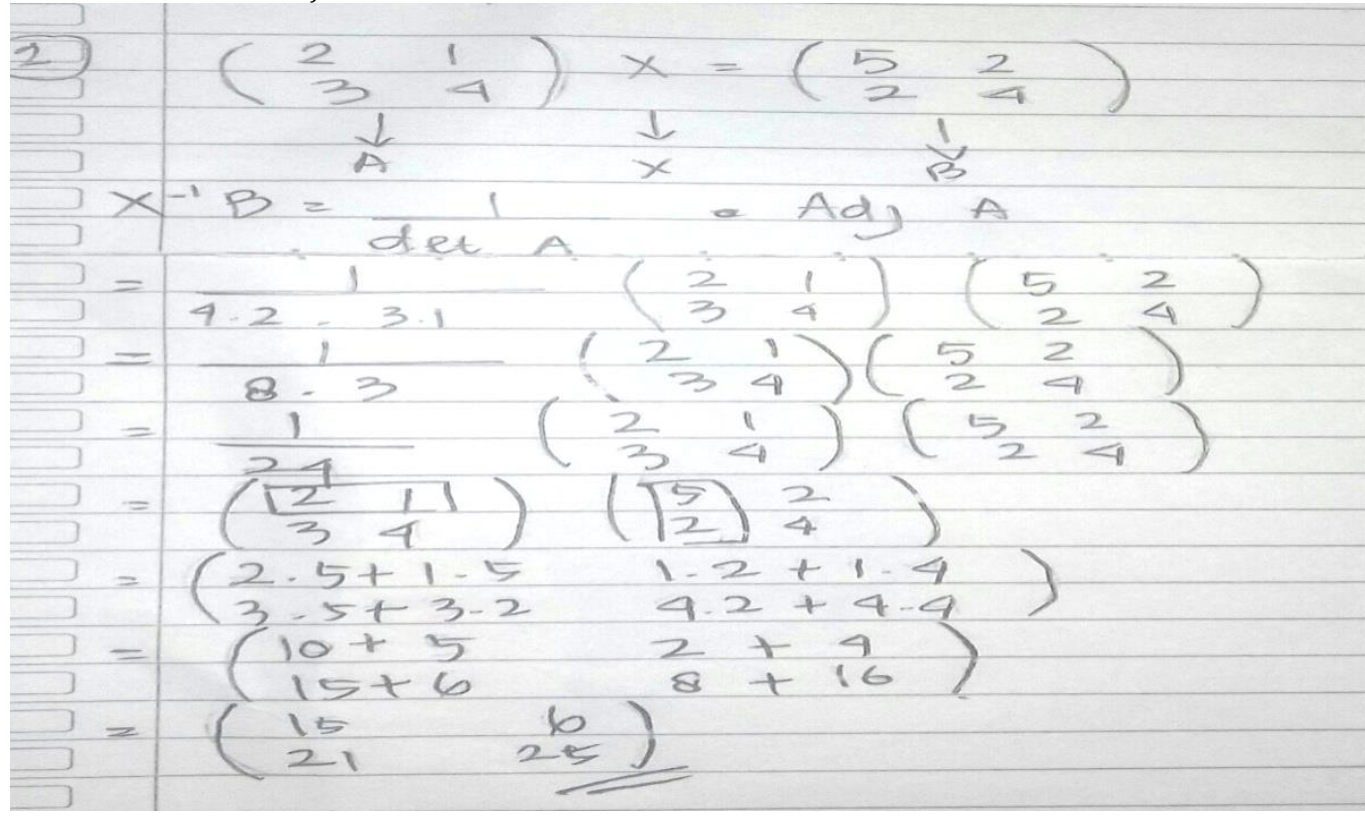

Gambar 2. Jawaban Soal Nomor 2

Berdasarkan hasil dari jawaban tertulis pada soal nomor 2, didapatkan beberapa kesalahan yang dilakukan oleh siswa, yaitu: Kesalahan dalam tidak memahami konsep persamaan matriks bentuk $A X=B$, Kesalahan dalam tidak memahami rumus persamaan matriks bentuk $A X=B$ sehingga salah dalam menentukan $A^{-1}$. Rumus $A^{-1}$ itu sendiri adalah $A^{-1}=$ $\frac{1}{\operatorname{det} A}$. adj $A$. Hal ini sejalan dengan penelitian Wijayanti (2010) menunjukan 
bahwa cukup banyak peserta didik yang mengalami kesulitan dalam mengerti rumus. Karena dalam mengerti rumus itu tidak hanya sekedar hafal saja namun dalam mengerti rumus peseta didik harus memahami dan mengerti.. Kesalahan dalam menentukan determinan seharusnya $\frac{1}{8-3}$ bukan $\frac{1}{8.3}$ sehingga determinananya adalah $\frac{1}{5}$, Kesalahan dalam menentukan adjoin A, menentukan adjoin A pada matriks berordo 2x2 dengan memperhatikan diagonal pertama $\left[\begin{array}{ll}2 & 1 \\ 3 & 4\end{array}\right]$ yaitu dengan memindahkan baris ke-2 kolom ke-2 pada baris ke-1 kolom ke-1 begitupun dengan baris ke-1 kolom ke-1 dipindahkan pada baris ke-2 kolom ke-2. Dan untuk baris ke-1 kolom ke-2 dan baris ke-2 kolom ke-1 berubah tanda menjadi negatif tanpa memindahkan posisi nya. Sehingga didapat adj $A=\left[\begin{array}{cc}4 & -1 \\ -3 & 2\end{array}\right]$. Karena Kesalahan-kesalahan tersebut maka didapat kesalahan pada hasil selanjutnya. Dan pada jawaban tersebut terlihat bahwa siswa belum dapat mengoperasikan matriks yaitu terlihat dalam hasil baris ke-2 kolom ke-1 dan baris ke-2 kolom ke-2. Karena kesalahan siswa pada pemahaman awal yaitu menentukan persamaan matriks bentuk $=B$. hal ini sejalan dengan pendapat Malau( 1996:44) mengatakan bahwa penyebab kesalahan yang sering dilakukan siswa dalam menyelesaikan soal-soal matematika dapat dilihat dari beberapa hal antara lain disebabkan kurangnya pemahaman atas materi prasyarat maupun materi pokok yang dipelajari, kurangnya penguasaan bahasa matematika, keliru menafsirkan atau menerapkan rumus, salah perhitungan, kurang teliti, lupa konsep. Berikut ini adalah jawaban tertulis siswa berdasarkan soal nomor 3:

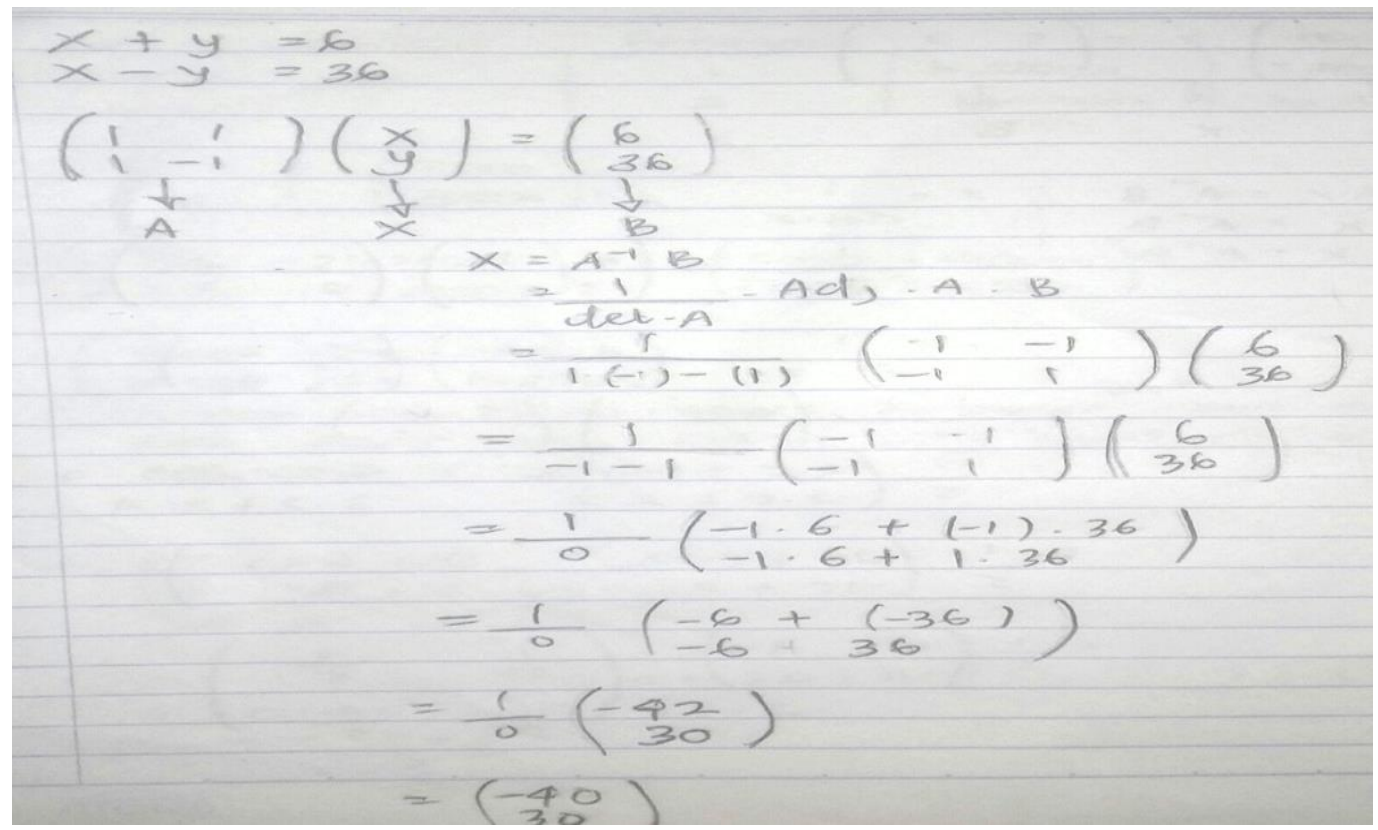

Gambar 3. Jawaban Soal Nomor 3 
Berdasarkan hasil dari jawaban tertulis pada soal nomor 3, didapatkan beberapa kesalahan yang dilakukan oleh siswa, yaitu: Kesalahan siswa tidak dapat mengubah kalimat pernyataan pada soal kedalam kalimat matematika. sehingga siswa salah dalam menentukan system persamaan linearnya, siswa sudah dapat mengubah sistem persamaan linear kedalam bentuk matriks. Namun karena siswa dalam menentukan sistem persamaan linearnya sudah salah, maka meskipun cara mengubah sistem persamaan linearnya sudah benar tetap saja hasil selanjutnyanya akan salah, kesalahan selanjutnya juga pada hasil determinan terlihat pada gambar 3 bahwa -1-1 bukan lah 0 melainkan -2. Jadi siswa masih salah dalam pengoperasian hasil bilangan. Karena siswa sudah melakukan kesalahan awal yaitu dalam mengubah pernyataan kedalam bahasa matematika maka siswa tersebut juga akan salah dalam menentukan hasil selanjutnya. Kesalahan-kesalahan tersebut sejalan dengan pendapat (abdurahman, 2003) mengemukakan berbagai kesalahan umum yang dilakukan oleh anak dalam mengerjakan tugas-rugas matematika, yaitu kurangnya pengetahuan dan symbol, kurangnya pemahamantentang nilai tempat, penggunaan proses yang keliru kesalahan perhitungan dan tulisan yang tidak dapat dibaca sehingga siswa melakukan kekeliruan karena tidak mampu lagi membaca tulisannya sendiri. Pendapat tersebut juga sejalan dengan pendapat Hidayat (2013:39) Beberapa kesalahan yang biasanya dilakukan siswa terkadang siswa memiliki gaya kognitif field independent lebih sering terjadi kesalahan pada fakta dan operasi, sedangkan untuk field dependent lebih sering terjadi kesalahan fakta, konsep, operasi dan prinsiplerner

Berdasarkan dari hasil analisis tersebut, dapat disimpulkan kesalahan siswa seperti yang tersaji dalam table dibawah ini.

Tabel 1. Deskripsi Kesalahan Jawaban Siswa

\begin{tabular}{ll}
\hline No & \multicolumn{1}{c}{ Deskripsi Kesalahan } \\
\hline 1. & Kesalahan dalam pengoperasian bilangan \\
2. & Kesalahan memahami konsep persamaan matriks bentuk $\boldsymbol{A} \boldsymbol{X}=\boldsymbol{B}$ \\
3. & Kesalahan dalam menentukan rumus $\boldsymbol{A}^{\mathbf{- 1}}$ \\
4. & Kesalahan dalam menentukan determinan pada matriks \\
5. & Kesalahan dalam menentukan adjoin matriks \\
6. & Kesalahan dalam mengubah soal cerita kedalam kalimat matematika \\
7. & Kesalahan dalam hasil perhitungan \\
8. & Kesalahan dalam melanjutkan proses penyelesaian \\
\hline
\end{tabular}


9. Kesalahan dalam menentukan hasil akhir

Setelah dilakukan analisis kesalahan jawaban siswa, selanjutnya peneliti memberikan angket motivasi belajar matematika. tujuannya yaitu untuk mengetahui kaitannya dengan kesalahan siswa dalam menjawab soal dengan motivasi belajar yang ada didalam diri siswa. Angket tersebut berisi pernyataan-pernyataan sebagai berikut.

1) Matematika merupakan pelajaran yang sulit

2) Anda tertarik belajar matematika karena guru menerangkan materi dengan jelas dan menyenangkan

3) Saya semangat belajar matematika karena matematika merupakan salah satu faktor penting bagi saya untuk masuk perguruan tinggi, dan dunia kerja kelak

4) Anda mengatasi kesulitan saat belajar matematika dengan bertanya atau berdiskusi dengan guru atau teman

5) Suasana belajar matematika yang saya alami biasanya menyenangkan

6) Dengan menguasai materi pada pelajaran matematika saya merasa lebih mudah menguasai mata pelajaran eksak lain seperti fisika, kimia, dan pelajaran eksak lainnya

7) Saya menyukai mengerjakan atau menyelesaikan soal-soal matematika

8) Saya senang mencari solusi atas masalah khususnya yang berkitan dengan pelajaran matematika

Berdasarkan hasil jawaban siswa pada angket yang sudah dibagikan dapat diambil kesimpualan bahwa

1) Siswa masih menganggap matematika adalah pelajaran yang sulit untuk dipahami. karena siswa dari awal sudah beranggapan bahwa matematika merupakan pelajaran yang sulit dipahami maka siswa sudah tidak termotivasi untuk mempelajari matematika dan ini menyebabkan kesalahan-kesalah siswa dalam menjawab soal matematika.

2) Siswa masih tertarik pada pembelajaran matematika apabila guru menerangkan atau menjelaskan materinya dengan jelas dan menyenangkan. Disini siswa masih bertumpu pada guru, siswa masih menganggap bahwa guru merupakan sumber pengetahuan. Jadi apabila guru menjelaskannya tidak menyenangkan maka siswa tidak termotivasi untuk belajar matematika dan ini akan berpengaruh pada hasil jawaban siswa dalam pembelajaran matematika. 
3) Siswa masih banyak yang tidak mengetahui bahwa matematika merupakan salah satu faktor penting untuk masuk keperguruan tinggi dan dunia kerja kelak. Oleh karenanya, siswa masih kurang termotivasi untuk mempelajari matematika.

4) Siswa masih enggan untuk bertanya atau berdiskusi kepada guru atau temannya jika merasa kesulitan. Biasanya dikarenakan takut bertanya, takut dikatakan bodoh karena ia tidak mengerti sendiri dan takut ditanya balik oleh gurunya ini yang menyebabkan siswa enggan bertanya maka yang didapat ialah kesalahan-kesalahan siswa dalam menjawab soal matematika.

5) Suasana belajar yang siswa alami biasanya kurang menyenangkan. karena pada dasarnya siswa sudah beranggapan bahwa matematika adalah pelajaran yang sulit yang terbayang hanyalah rumus-rumus yang membuat tidak menyenangkan.

6) Siswa memahami bahwa dengan menguasai mata pelajaran matematika ia akan merasa mudah mempelajari mata pelajaran eksak seperti fisika, kimia dan pelajaran eksak lainnya.

7) Siswa masih kurang minat dalam mengerjakan atau menyelesaikan soal-soal matematika. karena bagi siswa soal-soal matematika itu soal yang sulit untuk dipecahkan.

8) Siswa masih enggan mencari solusi atas masalah khususnya yang berkitan dengan pelajaran matematika. karena mereka beranggapan bahwa matematika merupakan permasalahan yang sulit untuk dipecahkan.

\section{KESIMPULAN DAN SARAN}

Berdasarkan hasil penelitian, dapat disimpulkan bahwa siswa melakukan 9 jenis kesalahan, yaitu Kesalahan dalam pengoperasian bilangan, kesalahan memahami konsep persamaan matriks bentuk $A X=B$, kesalahan dalam menentukan rumus $A^{-1}$, kesalahan dalam menentukan determinan pada matriks, kesalahan dalam menentukan adjoin matriks, kesalahan dalam mengubah soal cerita kedalam kalimat matematika, kesalahan dalam hasil perhitungan, kesalahan dalam melanjutkan proses penyelesaian, kesalahan dalam menentukan hasil akhir. Kesalahankesalahan tersebut ada kaiatannya dengan siswa sudah beranggapan bahwa matematika merupakan pelajaran yang sulit, guru masih menjadi pusat 
sumber pengetahuan, apabila guru menjelaskannya tidak meyenagkan maka akan berpengaruh pada pemahaman siswa, siswa masih banyak yang tidak mengetahui bahwa matematika merupakan faktor penting untuk masuk keperguruan tinggi dan dunia pekerjaan oleh sebab itu siswa kurang tertarik pada matematika, berpengaruh pada pemahaman siswa pada pembelajaran matematika, suasana belajar siswa kurang menyenangkan juga merupakan faktor dalam pemahaman siswa pada pembelajaran matematika, siswa enggan untuk bertanya dan berdiskusi kepada guru ataupun temannya, suasana belajar siswa yang biasa dialami kurang menyenangkan, siswa masih kurang minat dalam mengerjakan soal-ssoal matematika karena soalnya yang sulit untuk dipecahkan, dan siswa masih enggan untuk mencari solusi yang berkaitan dengan pembelajaran matematika. Setelah mengetahui deskripsi kesalahan-kesalahan dalam menyelesaikan soal matriks diharapkan guru dapat memberi penekanan pemahaman konsep materi matriks, khususnya dibagian yang siswa sering mengalami kesalahan, guru diharapkan dapat membangun suasana belajar yang menyenangkan, meyakinkan kepada siswanya bahwa matematika bukanlah pelajaran yang sulit yang dibayangkan, perbanyak memberi soal latihan agar siswa terbiasa dalam menyelesaikan soal-soal matematika, memancing siswa agar senang bertanya apa saja yang menjadi kesulitan dan yang tidak dipahami. menindaklanjuti penelitian ini dengan cara meneliti analisis kesalahan lebih lanjut

\section{DAFTAR PUSTAKA}

Rahmawati, A. (2017). Analisis Kesalahan Mahasiswa Pendidikan Matematika Dalam Menyelesaikan Soal Pertidaksamaan Pada Mata Kuliah Kalkulus I .Al-Jabar: Jurnal Pendidikan Matematika Vol 8, No. 1.

Cahyani, C. A, Sutriyono.(2018). Analisis Kesalahan Siswa Dalam Menyelesaikan Soal Pada Materi Operasi Penjumlahan, dan Pengurangan Bentuk Aljabar Bagi Siswa Kelas VII SMP Kristen 2 Salatiga. Jurnal Teori dan Aplikasi Matematika Vol 2, No. 1.

Layn, M.R, Kahar, M.S,.(2017). Analisis Kesalahan Siswa Dalam Menyelesaikan Soal Cerita. Jurnal Math Educator Nusantara. Vol 03, No. 02.

Yulia, R, Fauzi, Awaluddin.(2017). Analisis Kesalahan Siswa Mengerjakan Soal Di Kelas V SDN 37 BANDA ACEH. Jurnal Ilmiah Pendidikan Guru Sekolah Dasar. Vol2, No. 1. 
Happy, N. \& D. B. Widjajanti. (2014). Keefektifan PBL ditinjau dari kemampuan Berfikir kritis dan kreatif matematis, serta self esteem siswa SMP. Jurnal Riset Pendidikan Matematika Vol. 1 No. 1: 48-57.

Sholekah, L. M.,Anggreini, D., Waluyo A.(2017). Analisis Kesulitan Siswa dalam Menyelesaikan Soal Matematika Ditinjau dari Koneksi Matematis Materi Limit Fungsi.Wacana Akademika.1(2):151-158

Wiyartimi, dkk.(2010). Diagnosis Kesulitan Belajar Matematika Siswa pada Materi Trigonometri Rumus-rumus Segitiga.JMAP 9(2):89-99.

Malau,L.(1996). Analisis Kesalahan Jawaban Siswa Kelas 1 SMU Kampus

Nommense Pematang Siantar dalam Menyelesaikan Soal-soal Terapan SSiswa Persamaan 2 Variabel. Tesis tidak Diterbitkan. Malang: IKIP Malang

Hidayat, dkk. (2013). Analisis Kesalahan Siswa dalam Menyelesaikan Soal pada Materi Ruang Dimensi Tiga Ditinjau dari Gaya Kognitif Siswa kelas X SMA Negeri 7 Surakarta. Jurnal Pendidikan Matematika Solusi. Vol.1, No.1

Yusmin, Edy.(1996). Kesulitan Siswa dalam Mempelajari Objek Belajar Matematika. Pontianak: Unversitas Tanjungpura 